Brit. F. vener. Dis. (1971) 47, 179

\title{
Clinical evaluation of carbenoxolone in balanitis
}

\author{
G. W. CSONKA* AND M. MURRAY ${ }^{\star \star}$ \\ Central Middlesex Hospital, Park Royal, London, N.W.10
}

Balanitis may be due to known bacterial, viral, protozoal, or fungal infection when specific treatment is usually satisfactory; it may be associated with a tight foreskin when irrigation and subsequent circumcision are indicated. Some cases have an allergic basis or may be part of Reiter's syndrome and many more are of unknown aetiology and the customary treatment with topical hydrocortisone preparations has some measure of success. In these forms it is justifiable to try a new therapeutic approach and carbenoxolone sodium was chosen because of its reported favourable effect on ulcers and erosions involving mucous membranes (Avery Jones, 1965; Hunt, 1965; Samuel, 1967). In the present study 2 per cent. carbenoxolone gel was compared with 1 per cent. hydrocortisone cream B.P.C. in a double blind therapeutic trial.

\section{Methods}

Hydrocortisone cream and carbenoxolone gel were supplied in identical 5-g. tubes, which were randomized and numbered. Sixty patients with active balanitis were handed one of the tubes of ointment sequentially and instructed to apply it three times daily to the affected area for 7 days, after which they were to be seen again; they were told to attend earlier if the condition deteriorated. If, after 7 days, there was no measurable improvement, known carbenoxolone gel was given and the patient was asked to report after a further 7-day treatment.

The patients were seen again after 1 month and after 3 months for a final blood test for syphilis. All the cases were initially screened to exclude syphilitic and Candida

Received for publication October 5, 1970

*Consultant Venereologist

$\star \star$ Assistant Venereolozist balanitis but were otherwise not selected. Assessment was made blind before the code was broken.

Of the sixty patients included in the trial, thirty received hydrocortisone cream and thirty carbenoxolone gel, seven defaulted before they could be assessed and three were excluded because Candida was eventually isolated in two and psoriasis was found to be the cause of the penile lesion in one.

There thus remained fifty patients, 24 on hydrocortisone cream and 26 on carbenoxolone gel. 45 patients were Caucasian, four African, and one Indian; 26 were single and 24 married, a factor evenly distributed in the two treatment groups; only two patients were circumcised.

Chronicity was assumed if the symptoms had persisted for over one month. The balanitis was termed subacute if symptoms were present for 2 to 4 weeks and acute if under 2 weeks. The condition was graded as severe if there were marked and extensive erosions, moderate if erosions were slight or the lesions were erythematous but extensive, and slight if there were no erosions and only a mild or moderate degree of erythema.

Response to treatment was judged to be excellent if the balanitis cleared completely at the end of 7 days, moderate if there was marked improvement with a tendency to relapse as soon as treatment was discontinued, and none if there was no significant improvement.

\section{Results}

The results are shown in Table I. There is a preponderance of severe and chronic cases in the carbenoxolone-treated group. If all the patients are considered together, there is a bias in favour of carbenoxolone gel, but this is not statistically significant.

It is not possible to analyse separately the results in those with chronic balanitis since the numbers were too small and unequally divided between the treatment groups. However, if the results of treat-

TABLE I Response of fifty patients with balanitis to hydrocortisone cream or carbenoxolone gel

\begin{tabular}{|c|c|c|c|c|c|c|c|c|c|c|}
\hline \multirow{2}{*}{ Theraby } & \multirow{2}{*}{$\begin{array}{l}\text { Total no. } \\
\text { of cases }\end{array}$} & \multicolumn{3}{|c|}{ Chronicity } & \multicolumn{3}{|c|}{ Severity } & \multicolumn{3}{|l|}{ Response } \\
\hline & & Chronic & Subacute & Acute & Severe & Moderate & Slight & Excellent & Moderate & None \\
\hline $\begin{array}{l}\text { Hydrocortisone cream } \\
\text { Carbenoxolone gel }\end{array}$ & $\begin{array}{l}24 \\
26\end{array}$ & $\begin{array}{l}2 \\
8\end{array}$ & $\begin{array}{l}4 \\
3\end{array}$ & $\begin{array}{l}18 \\
15\end{array}$ & $\begin{array}{r}5 \\
12\end{array}$ & $\begin{array}{l}13 \\
9\end{array}$ & $\begin{array}{l}6 \\
5\end{array}$ & $\begin{array}{l}14^{\star} \\
19^{\star}\end{array}$ & $\begin{array}{l}5 \\
4\end{array}$ & $\begin{array}{l}5 \\
3\end{array}$ \\
\hline
\end{tabular}

*Difference not significant 
ment in acute and subacute balanitis are taken together, there is a clear advantage for carbenoxolone gel over hydrocortisone cream with a significantly greater number showing an 'excellent' response to cartenoxolone than to hydrocortisone $(P<0.04)$ (Table II).

TABLE II Treatment response in acute and subacute cases

\begin{tabular}{|c|c|c|c|c|}
\hline \multirow{2}{*}{ Therapy } & \multirow{2}{*}{$\begin{array}{l}\text { Total no. } \\
\text { of cases }\end{array}$} & \multicolumn{3}{|l|}{ Response } \\
\hline & & Excellent & Moderate & None \\
\hline $\begin{array}{l}\text { Hydrocortisone cream } \\
\text { Carbenoxolone gel }\end{array}$ & $\begin{array}{l}22 \\
18\end{array}$ & $\begin{array}{l}12^{\star} \\
16^{\star}\end{array}$ & $\begin{array}{l}5 \\
1\end{array}$ & $\begin{array}{l}5 \\
1\end{array}$ \\
\hline
\end{tabular}

- Significant difference $(P<0.04)$

Some patients who failed to respond to one trentment did well on the other. Out of six cases not influenced by hydrocortisone cream, five gavc an 'excellent' response and one a 'moderate' response to carbenoxolone gel, whereas two of those unaffected by carbenoxolone gel gave an 'excellent' response to hydrocortisone.

Five patients had associated Reiter's syndrome and in four of these carbenoxolone gel was very effective.

After the conclusion of the double-blind trial, seven patients were seen with fresh attacks of balanitis some 1 to 9 months after the previous attack and these responded to treatment in the same way as the earlier attacks. Thus two which had initially cleared promptly with carbenoxolone gel did so again and five which showed a moderate response to either hydrocortisone or carbenoxolone reacted similarly during the later episodes. This is well illustrated by one of the cases of Reiter's syndrome with severe erosive balanoposthitis which failed to respond to local hydrocortisone but cleared rapidly with carbenoxolone. This man had two further attacks of erosive balanoposthitis which again failed to respond to topical hydrocortisone but did respond to carbenoxolone gel (Figure).

\section{SIDE-EFFECTS}

No local or general side-effects were observed in any of the patients and in no instance did either treatment cause the balanitis to deteriorate.

\section{Discussion}

Carbenoxolone gel was found to be at least as effective as hydrocortisone cream, giving 73 per cent. of fully satisfactory results compared to 58.3 per cent.; this overall difference is, however, not significant. The acute and subacute cases responded better to carbenoxolone gel than to hydrocortisone
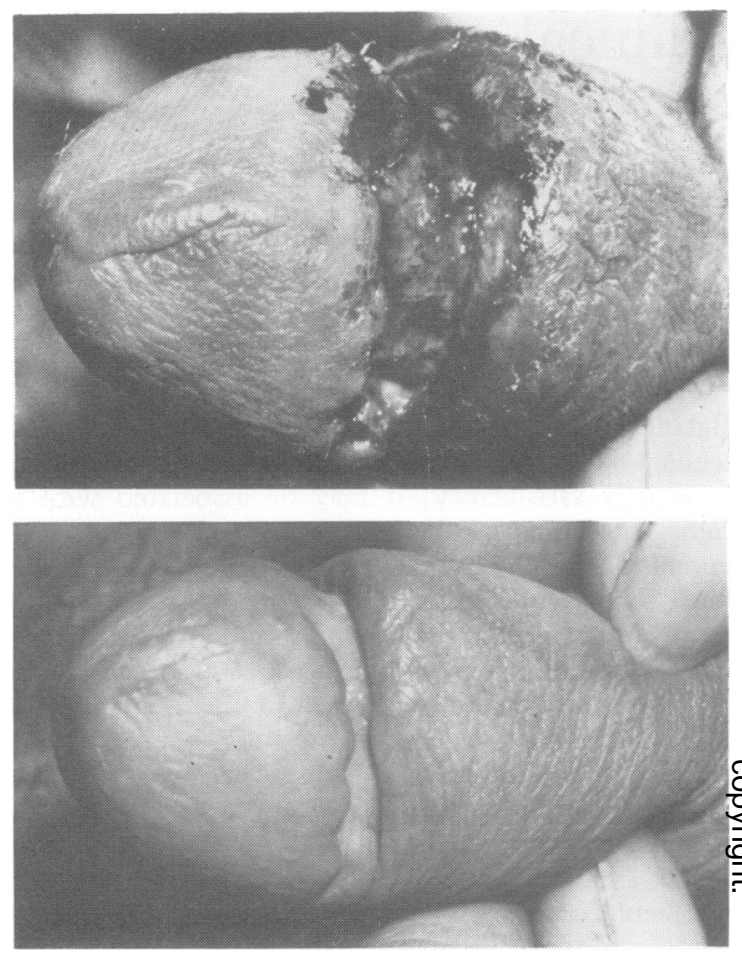

FIGURE Severe erosive balanoposthitis associated with Reiter's syndrome before and 2 weeks after treatment with carbenoxolone gel

cream. It was not possible to predict on clinical grounds which patient was likely to respond to either treatment. Carbenoxolone, like hydrocortisone, appears to have no anti-infective properties. Both have anti-inflammatory activity though carbenoxolone was shown to have only one-quarter to onethird the effect of hydrocortisone (Finney and Tárnoky, 1960). It is therefore probable that some additional pharmacological action by carbenoxolone is at least partly responsible for the therapeutic results. Recent experimental studies on the gastric mucosa have shown that carbenoxolone induces a decreased requirement for cell replacement, allowing healing to take place by compensating for the loss of epithelium (Lipkin, 1970). Whether a similar mechanism operates on mucous surfaces apart from the stomach has yet to be investigated. One favourable factor may lie in the formulation of the gel, which makes it adhere tenaciously to the difficult moist surface to be treated. It is concluded that carbenoxolone gel is a useful preparation in the treatment of balanitis which is not due to specific infection. 


\section{Summary}

In a controlled double-blind study, carbenoxolone gel was compared with hydrocortisone cream in the treatment of fifty patients with nonspecific balanitis. Carbenoxolone gel was found to be at least as effective as hydrocortisone cream, taking the group as a whole, and more effective in the acute and subacute cases. No adverse effects were produced by either preparation. It is considered that carbenoxolone gel is of value in the treatment of balanitis not due to specific infections.

We gratefully acknowledge the help of Dr. S. Gottfried of Biorex Laboratories who supplied carbenoxolone gel and hydrocortisone cream and arranged for statistical analysis.

\section{References}

FinNey, R. S. H., and TÁrNoky, A. L. (1960) f. Pharm. Pharmacol., 12, 49
Hunt, T. (1965) Med. Dig. (Lond.), 10, 222

JONes, F. AVERY (1965) Practitioner, 195, 698

LIPKIN, M. (1970) Paper read at the IV World Congress of Gastroenterology, Copenhagen

Samuer, O. W. (1967) Practitioner, 199, 220

Estimation de la valeur clinique du gel de Carbenoxolone dans la balanite

SOMMAIRE

Le gel de Carbenoxolone fut comparé à une crême à l'hydrocortisone dans une étude contrôlée à double insu lors du traitement de $\mathbf{5 0}$ malades atteints de balanite non spécifique. En considérant le groupe dans son entier, le gel à la carbenoxolone fut trouvé au moins aussi efficace que la crême à l'hydrocortisone, mais plus efficace dans les cas aigüs ou subaigüs. Aucun effet secondaire défavorable ne fut observé avec l'une ou l'autre des préparations. On conclut que le gel de Carbenoxolone a de la valeur dans le traitement de balanites non attribuables à des infections spécifiques. 